\title{
A KNOCK AROUND THE ECONOMIC IMPACT OF COVID-19 WITH REFERENCE TO THE QUANTUM OF GOODS AND SERVICES TAX COLLECTION IN INDIA
}

\author{
Dr. Baneswar Kapasi \\ Associate Professor, \\ Department of Commerce, \\ Kazi Nazrul University, Asansol \\ Paschim Bardhaman, \\ West Bengal, Pin - 713340
}

*Corresponding Author

\author{
Dr. Mahesh Kumar Kurmi * \\ Assistant Professor, \\ Department of Commerce, \\ Kazi Nazrul University, \\ Asansol \\ Paschim Bardhaman, \\ West Bengal, Pin - 713340
}

Article DOI: https://doi.org/10.36713/epra6977 DOI No: 10.36713/epra6977

\begin{abstract}
COVID -19 has wedged all the major economies across the globe significantly. The World Health Organisation (WHO) first declared COVID-19 as a world health emergency in January 2020. The virus originated in Wuhan, China, but has been detected in over 200 countries. Amid the Coronavirus Pandemic, several countries worldwide resorted to lockdown to control infection. Due to lockdown, the production and distribution chains have been disrupted across the lands. All the segments of the economy have been impacted in different magnitude, and this has a direct impact on GDP, unemployment ratio, and tax collection. Goods and Services Tax (GST) is a harmonized tax of different indirect taxes in India. The GST collection reflects the volume of economic activities in India. Thus, in this paper, an attempt has been made to assess the impact of Covid-19 on the Indian economy concerning the quantum of Goods and Service collection in Indian during the lockdown period. For this study, secondary data relating to GST collection have been pooled from the official websites of the GST Council of India for the last three years, i.e., 2018 to 2020, and pair t-test have been run for testing statistical significance of the impact of COVID-19 on the quantum of the collection of Goods and Service Tax in India before and after lockdown announcement after adjusting the inflation factor. The results indicate no significant difference in the quantum of Goods and Services Tax Collection in India before and after the lockdown announcement due to the COVID-19 outbreak but a loss of Rs. 1,41,837 crore owing to the low collection of GST from March 2020 to August 2020 gives us a clear message that we should undoubtedly rethink the plans in more structural and more viable ways to reach a position to absorb any kinds of uncertain threats from the external environment.

KEYWORDS: Covid-19, GST, Indian Economy, Pandemic, Lockdown
\end{abstract}

\section{INTRODUCTION}

Covid-19 has impacted every part of our life, whether it is our social life or economic, political life or religious. Although this untreatable virus originated from China, it has affected us much more poorly than China as we are not able to absorb the uncertain threats from the external environment. All the parts, especially the transport sector, including tour and travel, production, and distribution, have been badly impacted due to prolonged lockdown. In some cases, the lifestyles have been changed totally due to this Corona outbreak.

The most critical impact of the Covid-19 pandemic has been witnessed on the Indian economy, especially regarding employment and income generation. The majority of the Indian population depends upon daily income. This Covid-19 and subsequent prolonged lockdown made many populations of India unemployed. The low-income feature of the Indian economy has created a vicious circle on the low-income group of people. The second significant impact of Covid-19 on the Indian economy can be seen in the transport and distribution system. Covid-19's third impact on the Indian economy can be seen as consumer spending, as consumer spending has been the worst hit due to the loss of daily income jobs.

Goods and Services Tax in India is a harmonized indirect tax on a PAN India basis. Significant indirect taxes are subsumed with the GST. It indicates economic activities in terms of production, trade, commerce, and consumption. 
Indirectly it also implies the magnitude of employment in India. Hence, the economic impact can be assessed through the quantum of collection of GST.

\section{SURVEY OF EXISTING LITERATURE}

There is no good number of studies conducted so far on the impact of Covid-19 on the Indian economy. Different news report of electronic and print media has conducted few studies on this issue. Different economic and financial agencies have also undertaken few studies to assess the impact of Covid19 on the Indian economy regarding various economic indicators and economic sectors.

J.D Sonkhaskar (2020), through his article 'Impact Of Covid-19 on Indian Economy', attempted to give an overview of the Covid-19 situation in India, the state of the Indian economy before the pandemic, its impact on different sectors of the economy, policy recommendation and strategies designed by the Indian government to lower the financial disaster. $\mathrm{He}$ has elaborated the influence of the pandemic situation sector-wise and suggested the different strategies for minimizing the economic losses in Indian scenario.

Agarwala, Shubhi and Singh, Archna (2020) put an effort to depict the waves of Covid-19 on different sectors of the Indian economy in their study 'Covid19 and Its Impact on Indian Economy. He has also made an effort to endow the government policy framework in this regard. Authors have also focused on those economic sectors that grasp a boost due to the outbreak of covid-19. They considered secondary data to judge the economic conditions from December 2019 to May 2020. Interestingly they provided twenty-four suggestions for minimizing the impact of the pandemic on the Indian economy after considering the effects of the pandemic on-demand front, supply front, financial market, and international trade, and economic growth.

HaiYue Liu et al. (2020) have conducted a study on the COVID-19 Outbreak and Affected Countries Stock Markets Response. They have evaluated the short-term impact of Covid-19 through event study methodology on twenty-one leading the stock market. They have concluded that the effects of the Covid-19 on Asian Countries are negatively abnormal after Covid-19 compared to other Countries.

M. Chaudhary, P. R. Sodani, and S. Das (2020), through their article "Effect of COVID-19 on Economy in India: Some Reflections for Policy and Programme," have assessed the bearing of Corona outbreak on affected sectors. They have highlighted the impact of Covid-19 on aviation, tourism, tourism, retail, capital markets, MSMEs, and Oil sectors. They have suggested that the policymakers of India must rethink the development paradigm more inclusively with the help of some reforms in the area of the labour market.

Most of the studies have been conducted to assess the impact of Covid-19 on the Indian economy regarding the demand-supply chain, international trade, financial market, stock market, and economic growth. However, hardly any study has been conducted to assess the impact of Covid-19 with reference to the quantum of Goods and Services Tax Collection in India.

\section{OBJECTIVES OF THE STUDY}

This study aims to assess the economic impact of COVID-19 with reference to the quantum of Goods and Services Tax collection in India.

\section{HYPOTHESIS OF THE STUDY}

To attain the above stated objective of the study, the following null hypothesis is to be tested in this regard:

Null Hypothesis $\left(\mathrm{H}_{0}\right)$ : There is no significant difference in quantum of Goods and Services Tax collection in India before and after lockdown announcement due to COVID-19 outbreak.

Alternative Hypothesis $\left(\mathrm{H}_{1}\right)$ : Rejection of Null Hypothesis implies a statistically significant difference in quantum of Goods and Services Tax collection in India before and after the lockdown announcement due to the COVID-19 outbreak.

\section{RESEARCH METHODOLOGY}

Secondary Data relating to GST collection have been pooled from the official websites of the GST Council of India. In addition to that, data pertaining to the Consumer Price index have been collected from the relevant industry website.

For adjusting inflation factors on GST collection, the data of 2018 and 2019 have been converted at the price level of 2020 . After converting the GST collection of 2018 and 2019, a paired t-test has been run for calculating the statistical significance of COVID-19 on the collection of Goods and Service Tax. The conversion factor for converting GST collection in 2018 at the price level of $2020=\mathrm{CPI}_{20} / \mathrm{CPI}_{18}$. Similarly, the Conversion factor for converting GST collection in 2019 at the price level of $2020=\mathrm{CPI}_{20} / \mathrm{CPI}_{19}$

After collecting and converting the data into the current price level, analysis has been done by comparing the quantum of GST collection for the period from April 2020, i.e., from the announcement of lockdown by the Indian Government to December 2020 with the average quantum of GST collection for the period from April to December of 2018 and 2019 at the price level of 2020 to conclude the economic impact of Covid-19 concerning the quantum of Goods and Services Tax Collection in India. 
EPRA International Journal of Multidisciplinary Research (IJMR) - Peer Reviewed Journal Volume: 7 | Issue: 5 | May 2021|| Journal DOI: 10.36713/epra2013 || SJIF Impact Factor 2021: 8.047 || ISI Value: 1.188

\section{FINDINGS AND DISCUSSIONS 6.1 COLLECTION OF GOODS AND SERVICE TAX (GST): GAIN/ LOSS ANALYSIS}

Goods and Service Tax in India is a single indirect tax that combines different indirect taxes levied on goods and services in India. Goods and Service Tax includes Central Goods and Service Tax (CGST), State Goods and Services Tax (SGST), Union Territory Goods and Services Tax (UTGST), Integrated Goods and Services Tax (IGST). Goods and Services Tax is collected on every stage of value addition in production, distribution, and consumption. It is a destination-based consumption tax that reflects the production and the consumption or demand. Goods and Services Tax is also collected on services, and therefore the economic activities relating to services can also be assessed using the quantum of Goods and Services Tax collection.

GST collection directly or indirectly indicates the level of economic activities in terms of trade, commerce, production, distribution, and consumption in the country. Higher GST collections represent an increase in economic activities like production, distribution, and consumption. Similarly, lower GST collections epitomize the downtrend of economic activities.

Table -1: Monthly GST Collection (Rs.) (In Crore) along with YoY Growth Rate

\begin{tabular}{|c|c|c|c|c|c|}
\hline Months & $\begin{array}{c}2018 \\
\text { (Rs. In Crore) }\end{array}$ & $\begin{array}{c}2019 \\
\text { (Rs. In Crore) }\end{array}$ & $\begin{array}{c}\text { YoY Growth } \\
\text { Rate }(\%) \\
\text { from the Year } \\
2018 \text { to } 2019\end{array}$ & $\begin{array}{c}2020 \\
\text { (Rs. In Crore) }\end{array}$ & $\begin{array}{c}\text { YoY Growth } \\
\text { Rate (\%) } \\
\text { from the Year } \\
2019 \text { to } 2020\end{array}$ \\
\hline January & 89,825 & $1,02,503$ & 14.11 & $1,10,828$ & 8.12 \\
\hline February & 85,962 & 97,247 & 13.13 & $1,05,366$ & 8.35 \\
\hline March & 92,167 & $1,06,577$ & 15.63 & 97,597 & -8.43 \\
\hline April & $1,03,459$ & $1,13,865$ & 10.06 & 32,172 & -71.75 \\
\hline May & 94,016 & $1,00,289$ & 6.67 & 62,151 & -38.03 \\
\hline June & 95,610 & 99,939 & 4.53 & 90,917 & -9.03 \\
\hline July & 96,483 & $1,02,083$ & 5.80 & 87,422 & -14.36 \\
\hline August & 93,960 & 98,202 & 4.51 & 86,449 & -11.97 \\
\hline September & 94,442 & 91,916 & -2.67 & 95,480 & 3.88 \\
\hline October & $1,00,710$ & 95,379 & -5.29 & $1,05,155$ & 10.25 \\
\hline November & 97,637 & $1,03,491$ & 6.00 & $1,04,963$ & 1.42 \\
\hline December & 94,725 & $1,03,184$ & 8.93 & $1,15,174$ & 11.62 \\
\hline
\end{tabular}

Table-1 indicates monthly GST collection in India from January 2018 to December 2020. The above table shows that the GST collection has been amply crushed from April 2020 to August 2020. The GST collection was Rs 89,825 crore in the month of January 2018, and it was accounted for Rs 1,02,503 crore in the month of January 2019, which indicates $14.11 \%$ growth on a Year-on-Year basis. GST collection in the Month of January 2020 was accounted for Rs 1,10,828 crore, showing 8.12\% growth on a Year-on-Year basis. A declining and updown trend in GST collection is noticed from March 2020 to August 2020. Total GST collection was amounting to Rs 1,03,459 crore in the month of April 2018 , and it was accounted for Rs 1,13,865 crore in the month of April 2019 that representing 10.06\% growth on a Year-on-Year basis. Total GST collection was amounting to Rs 32,172 crore in the month of April 2020, which reflects $71.25 \%$ negative growth on a Year-on-Year basis.

Similarly, total GST collection was amounting to Rs 94,016 crore in the month of May 2018, and the same was amounting to Rs $1,00,289$ crore in the month of May 2019 that signifies a $6.67 \%$ growth in total GST collection on a Year-on-Year basis. The entire GST collection for the month of May 2020 was amounting to Rs 62,151 crore that shows 38.03\% negative growth on a Year-on-Year basis. Recovery in the total GST collection was started from the month of September 2020. The monthly collection of data has also been depicted through chart one that reflects the last three years collection of GST (Rs. in crore) in India. 
EPRA International Journal of Multidisciplinary Research (IJMR) - Peer Reviewed Journal Volume: 7 | Issue: 5 | May 2021|| Journal DOI: 10.36713/epra2013 || SJIF Impact Factor 2021: 8.047 || ISI Value: 1.188

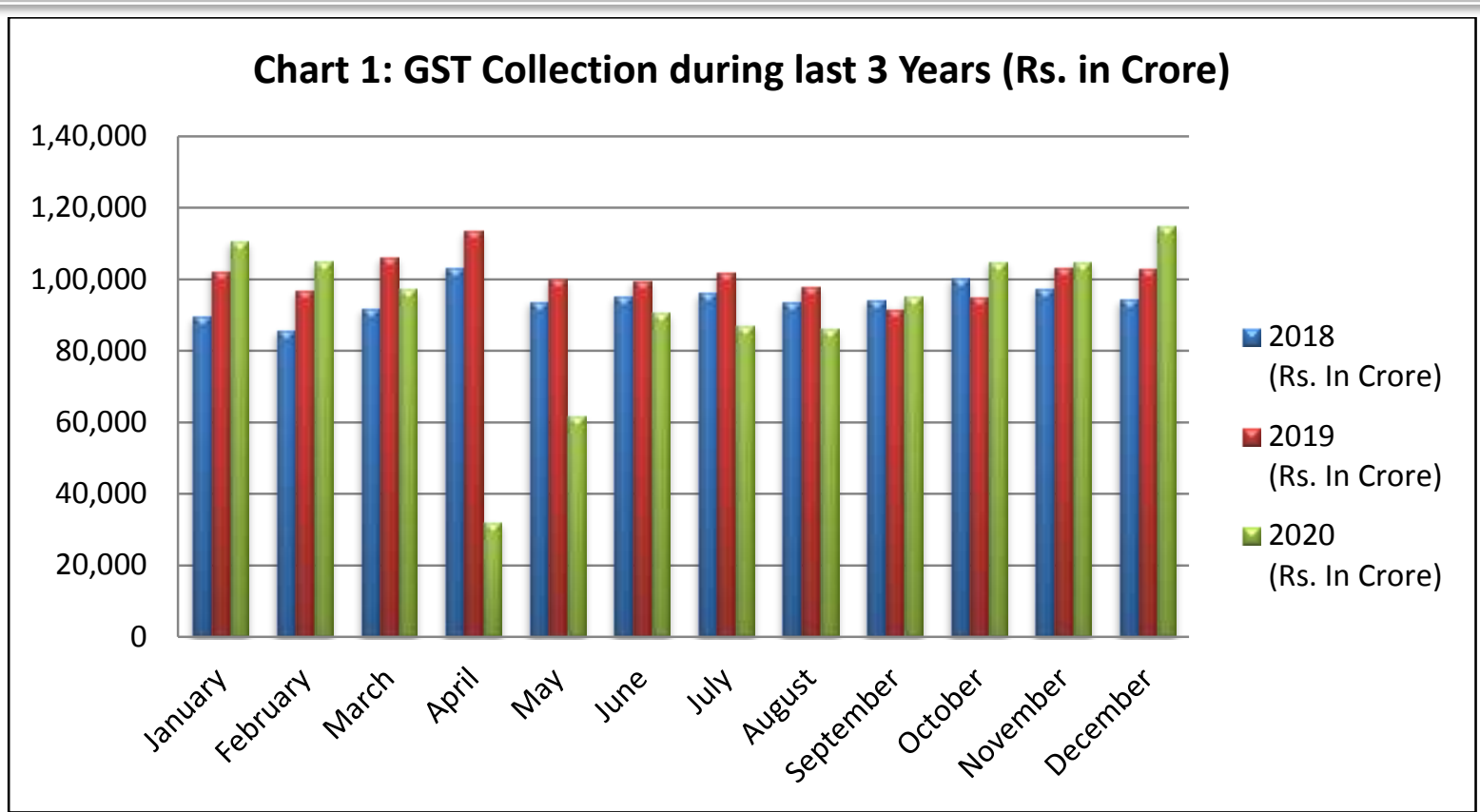

Comparative YoY Growth Rate (\%) from the Year 2018 to 2019 and YoY Growth Rate (\%) from the Year 2019 to 2020 have been portrayed through Chart 2 .

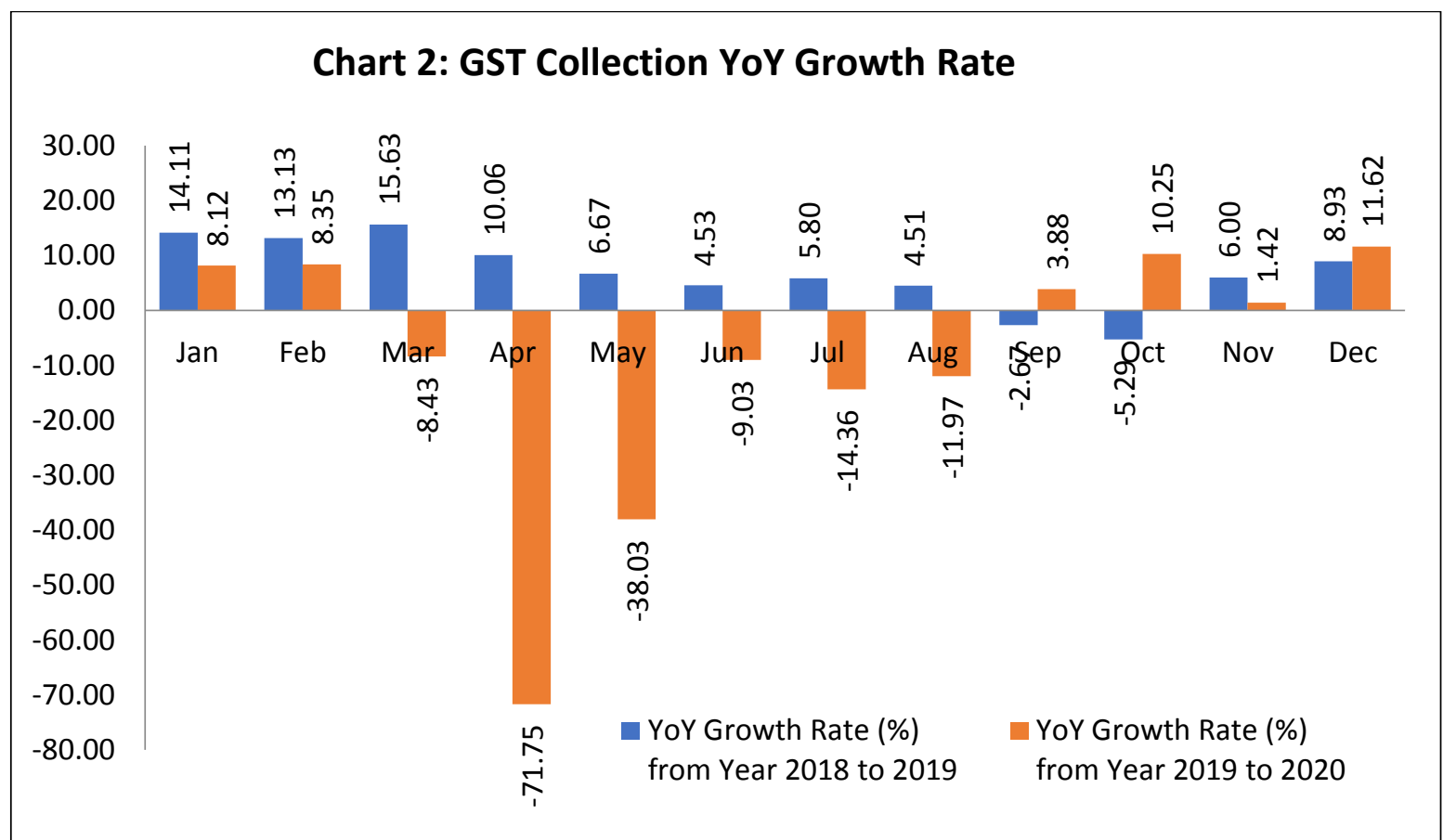

Table-2 depicts the GST collection of 2018 and 2019 at the price level of 2020 and the loss of GST collection during the lockdown period in India due to the COVID-19 outbreak. The maximum loss is seen in April 2020, a month of complete lockdown followed by May 2020. Loss of GST collection at the price level of 2020 is also seen in the month of July and August 2020, but the quantum of loss is relatively lower than the month of April and May because of partial lockdown. However, recovery of loss of GST collection is noticed from the month of September 2020. Total loss of GST collection was accounted for Rs 1,41,837 crore from March 2020 to August 2020. 
EPRA International Journal of Multidisciplinary Research (IJMR) - Peer Reviewed Journal Volume: 7 | Issue: 5 | May 2021|| Journal DOI: 10.36713/epra2013 || SJIF Impact Factor 2021: 8.047 || ISI Value: 1.188

Table-2: Goods and Service Tax Collection at the Price level of 2020) (Rs. in Crore)

\begin{tabular}{|l|c|c|c|c|c|}
\hline Months & $\begin{array}{c}\text { Amount of GST } \\
\text { collected in 2018 } \\
\text { at 2020 price } \\
\text { level (Rs. In } \\
\text { Crore) }\end{array}$ & $\begin{array}{c}\text { Amount of GST } \\
\text { collected in 2018 } \\
\text { at 2020 price } \\
\text { level (Rs. In } \\
\text { Crore) }\end{array}$ & $\begin{array}{c}\text { Monthly } \\
\text { Average }\end{array}$ & $\begin{array}{c}\text { Amount of } \\
\text { GST Collected } \\
\text { in 2020 } \\
\text { (Rs. In Crore) }\end{array}$ & $\begin{array}{c}\text { GST } \\
\text { Gain/Loss } \\
\text { (Rs. In Crore) }\end{array}$ \\
\hline January & 95,555 & $1,06,115$ & $1,00,835$ & $1,10,828$ & 9,993 \\
\hline February & 90,479 & 99,444 & 94,961 & $1,05,366$ & 10,405 \\
\hline March & 95,416 & $1,07,021$ & $1,01,219$ & 97,597 & $-3,622$ \\
\hline April & $1,05,135$ & $1,12,079$ & $1,08,607$ & 32,172 & $-76,435$ \\
\hline May & 93,380 & 96,908 & 95,144 & 62,151 & $-32,993$ \\
\hline June & 95,771 & 98,129 & 96,950 & 90,917 & $-6,033$ \\
\hline July & 97,368 & $1,01,831$ & 99,599 & 87,422 & $-12,177$ \\
\hline August & 95,446 & 98,606 & 97,026 & 86,449 & $-10,577$ \\
\hline September & 96,004 & 93,128 & 94,566 & 95,480 & 914 \\
\hline October & $1,02,196$ & 96,786 & 99,491 & $1,05,155$ & 5,664 \\
\hline November & 99,725 & $1,05,099$ & $1,02,412$ & $1,04,963$ & 2,551 \\
\hline December & 99,869 & $1,05,868$ & $1,02,869$ & $1,15,174$ & 12,305 \\
\hline
\end{tabular}

\subsection{TESTING OF HYPOTHESIS}

To achieve the specific objective of the study and to test the research hypothesis, paired t-test has been applied here. Here GST collection has been divided into two categories: Variable 1- Average monthly GST collection of year 2018 and 2019 at the price level of 2020 for the period April to December and Variable 2- GST collection from April 2020 to December 2020.

Table 3 : Result of Paired t-Test

\begin{tabular}{|l|c|c|}
\hline & Variable 1 & Variable 2 \\
\hline Mean & 99629.32499 & 86653.66667 \\
Variance & 19819346.5 & 644535688.5 \\
Observations & 9 & 9 \\
Pearson Correlation & -0.3251805 & \\
Hypothesized Mean Difference & 0 & \\
Df & 8 & \\
t Stat & 1.433056703 & \\
$\mathrm{P}(\mathrm{T}<=t)$ one-tail & 0.094870096 & \\
$\mathrm{t}$ Critical one-tail & 1.859548038 & \\
$\mathrm{P}(\mathrm{T}<=\mathrm{t})$ two-tail & 0.189740193 & \\
$\mathrm{t}$ Critical two-tail & 2.306004135 & \\
\hline
\end{tabular}

Since the calculated $\mathrm{p}$-value $(0.1897)$ is more than 0.05 , we cannot reject the null hypothesis, indicating any significant difference in the quantum of Goods and Services Tax Collection in India before and after the lockdown announcement due to the COVID-19 outbreak.

\section{CONCLUSION}

The Covid-19 has distorted the Indian economy in unpredictable ways during the lockdown period. The lockdown nature was unique, unexpected due to demand shock, supply shock, and market shock. Due to the lockdown for COVID-19, the Indian economy has affected all other economies differently. Goods and Service Tax collection is a variable that combines different economic parameters. It indicates production, consumption, income, employment, etc. Though the above study demonstrates no significant difference in quantum of Goods and Services Tax Collection in India before and after lockdown announcement due to COVID-19 outbreak, if we observe the first six months of lockdown period, we can say that the Indian economy suffers a loss of Rs. 1,41,837 crore due to 
low collection of GST from March 2020 to August 2020. This negative impact on GST collection indirectly indicates how the Indian economy and different sectors have impacted during the lockdown period. This impact has a long-term bearing on the Indian economy in GDP, employment, trade, and commerce. The policymakers should undoubtedly rethink the plans in more structural and more viable ways to reach a position to absorb the uncertain threats in any form from the external environment. This Covid outbreak gives us a clear message to adopt a sustainable development model based on inclusive growth and self-reliance.

\section{REFERENCES}

1. Agarwal, Shubhi and Archna, Singh (2020), "Covid-19 and Its Impact on Indian Economy", International Journal of Trade and CommerceIIARTC, Vol. 9, No. 1, pp. 72-79

2. HaiYue Liu, Aqsa Manzoor, CangYu Wang, Lei Zhang and Zaira Manzoor (2020), "The COVID-19 Outbreak and Affected Countries Stock Markets Response", International Journal of Environmental Research and Public Health

3. J.D Sonkhaskar (2020), "A Study on Impact of Covid-19 on Indian Economy”, International Journal of Advanced Science and Technology, Vol.29, No. 12s, pp.432-439

4. M Chaudhary, P. R. Sodani and S Das (2020), "Effect of COVID-19 on Economy in India: Some Reflections for Policy and Programme", Journal of Health Management, Vol. 22, No. 2, pp. 169180

ANNEXURE

Table 4: Wholesale Price Index

\begin{tabular}{|l|c|c|c|c|c|}
\hline Year (WPI) & $\mathbf{2 0 1 8}$ & $\mathbf{2 0 1 9}$ & $\mathbf{2 0 2 0}$ & $\mathbf{( P I 2 0 2 0 / P I 2 0 1 8 )}$ & (PI2020/PI2019) \\
\hline January & 116 & 119.2 & 123.4 & 106.38 & 103.52 \\
\hline February & 116.1 & 119.5 & 122.2 & 105.25 & 102.26 \\
\hline March & 116.3 & 119.9 & 120.4 & 103.53 & 100.42 \\
\hline April & 117.3 & 121.1 & 119.2 & 101.62 & 98.43 \\
\hline May & 118.3 & 121.6 & 117.5 & 99.32 & 96.63 \\
\hline June & 119.1 & 121.5 & 119.3 & 100.17 & 98.19 \\
\hline July & 119.9 & 121.3 & 121 & 100.92 & 99.75 \\
\hline August & 120.1 & 121.5 & 122 & 101.58 & 100.41 \\
\hline September & 120.9 & 121.3 & 122.9 & 101.65 & 101.32 \\
\hline October & 122 & 122 & 123.8 & 101.48 & 101.48 \\
\hline November & 121.6 & 122.3 & 124.2 & 102.14 & 101.55 \\
\hline December & 119.7 & 123 & 126.2 & 105.43 & 102.60 \\
\hline
\end{tabular}

